\title{
COMPUTATIONAL AFFORDANCES, CONTEXT COLLAPSES AND OTHER CHALLENGES TO LINGUISTIC STUDIES
}

\section{AFFORDANCES COMPUTACIONAIS, COLAPSOS DE CONTEXTO E OUTROS DESAFIOS PARA OS ESTUDOS LINGUÍSTICOS}

\section{Vinícius Vargas Vieira dos Santos*}

\begin{abstract}
With the increasing incorporation of digital media in 21 st century societies, a paradigmatic phenomenon is occurring on the language issue: communicative practices have started being widely mediated by technology. Besides incorporating earlier technologies, such as radio and television, computers have enabled users, who were mere passive recipients, to become information emitters as well. Starting from the principle pointed out by Marshall McLuhan (1964) that the medium controls the scales and actions configured in language, this paper seeks to understand the scalar levels of new technologies contexts and how they reverberate on meditated linguistic practices. Digital media are considered here as their own computational designs, communication channels that, far from being neutral, are previously set by large computational companies and, therefore, present ideologies and already configured forms of interaction, stimulating semiotic and pragmatic dimensions of language, reflecting on aspects of culture and, consequently, on political life.
\end{abstract}

Keywords: medium $;$ computational design; context collapse.

\section{RESUMO}

Com a crescente incorporação das mídias digitais nas sociedades do século XXI, ocorreu um fenômeno paradigmático na questão da linguagem: as práticas comunicativas começaram a ser amplamente mediadas pela tecnologia. Além de incorporar tecnologias anteriores, como rádio e televisão, os computadores permitiram que os usuários, que eram meros destinatários passivos, também se tornassem emissores de informação. Partindo do princípio apontado por Marshall McLuhan (1964) de que o meio controla as escalas e ações configuradas na linguagem, este artigo procura entender os níveis escalares dos contextos de novas tecnologias e como eles repercutem nas práticas linguísticas intermediadas. A mídia digital é considerada aqui a partir de seus próprios designs computacionais, canais de comunicação que, longe de serem neutros, são previamente estabelecidos por grandes empresas computacionais e, portanto, apresentam ideologias e formas de interação já configuradas, estimulando dimensões semióticas e pragmáticas de linguagem, refletindo sobre aspectos da cultura e, consequentemente, sobre a vida política.

Palavras-chave: meio; $_{i}$ design computacional ${ }_{i}$ colapso de contexto.

\footnotetext{
* Universidade Federal de Goiás, UFG, Goiânia, GO, Brasil. vargasvinicius2@gmail.com

Orcid: https://orcid.org/0000-0002-1529-0181
} 


\section{INTRODUCTION}

The digital media revolution occurred with surprising speed, changing the landscape of mass communications and, consequently, presenting challenges for linguistic studies. The mediation of linguistic practices by technologies such as cell phones, tablets, and computers connected to the internet, has promoted forms of communication different from the traditional aspects of speech and writing (CRYSTAL, 2001). Some characteristics of this new scenario are non-simultaneous feedbacks, plurality of simultaneous interactions, editing and manipulation of messages and hypertextuality.

In this paper I point to certain challenges that technological mediation presents to language studies, especially with regard to stimulating scalar transformations about meaning and linguistic performance. The concept of scale is considered here as "spatial scope, temporal durability, social reach" (BLOMMAERT; RAMPTON, 2011, p.9), subsequently, this paper examines how changes to these scalar factors in digital environments, stimulate and update performative practices of language. These changes range from the desires or intensions of the speaker at the level of the illocutionary (AUSTIN, 1963), to the effects of the linguistic act on the listener or audience at the level of the perlocutionary.

Another crucial subject considered in this paper is the permissiveness and limitations provided by software for linguistic practices. I demonstrate that the nature of the software, or more precisely its design, is relevant to the analysis of contemporary linguistic practice. Software is both interactive contact and context (or a part of that), because many communicative practices occurs in multimedia environments, such as political interactions.

\section{THE MEDIUM: MCLUHAN'S CONTRIBUTION}

Channel for Roman Jakobson (1960) is the physical element of message transmission, indispensable for communicative practices. "To be operative the message requires (...) finally, a CONTACT, a physical channel and psychological connection between the addresser and the addressee, enabling both of them to enter and stay in communication" (JAKOBSON, 1960, p. 353). Restricted to its ability to function or not, sometimes operating with noise leading to a hampering on communicative practices, the channel did not receive enough attention of linguistic studies if compared to other important contextual markers, such as the speaker's social place and the historical moment of the utterance. 
In this paper, I consider the channel (medium) as an indispensable context element for understanding new phenomena of language, such as social bots and fake news, for example. I explain that interaction technologies, acting as intermediaries of language practices, stimulate new scales and language resources on users.

This new scenario encourages us to return to a specific author who, in 1964, insisted that the medium is the message because "it is the medium that shapes and controls the scale and form of human association and action" (MCLUHAN, 1964, p.9). Taking McLuhan (1964) into consideration, we can understand that digital interfaces such as smartphones and computers demarcate scales and semiotic resources for the realization of communicative act, because interfaces modulate and alter contextual markers. Therefore, we can assume that linguistic practices, occurring via social networks (WhatsApp, Facebook, Twitter and others), are compromised with the permissiveness provided by the software, not only in terms of scale, but consequently in the semantic scope and pragmatic resources.

Edgar Allan Poe's tale (1842/1984), Descent to the Maelstrom, is used by McLuhan (1964) as an allegory on individuals' relationship with the technological means of communication. Allan Poe tells the story of a fisherman trapped in a water vortex and he is only able to survive because he learns how some objects behave within the water spiral, then he becomes able to create an escape strategy. According to McLuhan (1964), technology puts us before vortexes, because it anesthetizes human functions and perceptions, as we become a part of it. To the author, technologies are capable of extending the senses, the body and the mind, as the clothes extend the skin, the glasses extend the vision, the chair extends the hips and the cutlery extends the hands. Thus, human language tools, such as computers, could be extensions of the body and mind in language practices. Like Allan Poe's character, only by learning patterns pertaining to these new media, we can conceive ways to transgress the implicit anesthetic effects. The challenge, therefore, is to be able to spot patterns and media structures in which we are immersed since the dominant medium is always beyond our perception.

McLuhan (1964) presents a conceptual distinction between the message and the content to which a message links to. For the author, the message brings in its own format a meaning that does not depend on its linked content. The metalinguistic language of cubist painting exemplifies this theory, because regardless of the theme presented on the canvas, the meanings of cubist grammar will be present: "the inside and outside, the top, bottom, back, and front and die rest, in two dimensions, drops the illusion of perspective in favor of instant sensory awareness of the whole"(MCLUHAN, 1964, p 28). 
Following McLuhan's logic, I ask: what is the grammar of the new media that mediates linguistic practices in the 21 st century? For instance, regardless of their content, posts on Facebook - a report of authority abuse, a music video or even a love declaration - are similar, since all of them are configured by the same medium grammar: the quick overlap by others posts, permission to like and share, algorithms that sort out the content to be seen by this or that user, among other possibilities permitted by a given computational design. McLuhan's theory (1964) explains that the medium is not "neutral, a mere instrument, not just the transmitter"1 (SOUSA, CURVELLO, RUSSI, 2012, p. 3) of communication, but a configuration that has consequences for social life.

Although McLuhan's theory was elaborated a few decades before the digitization of social life, his theory is a significant contribution to understanding how technologies of the $21^{\text {st }}$ century have stimulated profound transformations in different aspects of human culture. For Rajagopalan (2012) although McLuhan did not witness the "true outbreak of the internet on a large scale, (...) the signs of the revolution to happen were clearly on his radar"2 (RAJAGOPALAN, 2012, p.42). Rajagopalan (2012) uses McLuhan's thinking about means and messages to deal with the challenges that the new internet language, Internetese, presents to Linguistics. Internetese is characterized, among other aspects, by abbreviating words, using imagery-symbolic characters (emotions) and reducing the use of punctuation marks, a form of language that carries the creative use of writing, casting aside the institutional rules of normative grammar. For Rajagopalan (2012), the determinant of the internet's abbreviations and speed is the internet itself, and not the fact that the Internetese simulates speech's informalities, it exemplifies "the phenomenon of the medium shaping the message, in the way that Marshall McLuhan envisioned" ${ }^{3}$ (RAJAGOPALAN, 2012, p.41).

\section{THE COMPUTATIONAL DESIGN: AN AFFORDANCE}

The Web 2.0 services platform that supports the current online digital environment has been characterized by the rapid accumulation of diverse data (big data) and can be measured by the variables of volume, variation and velocity $3 \mathrm{Vs}$

1. "[...] neutro, um mero instrumento, nem somente o transmissor" (Translated by me)

2. "verdadeira eclosão da internet em larga escala, (...) os sinais da revolução a acontecer estavam claramente em seu radar" (Translated by me)

3. "o fenômeno do meio moldar a mensagem, na forma que Marshall McLuhan vislumbrou" (Translated by me) 
(ZIKOPOULOS et al., 2012). Another important characteristic of big data is the distinction between structured (organized information for analysis) and unstructured data (which are clustered without an organizational logic). The latter corresponds to most of daily data accumulated on the web, such as posts on social networks. Considering that $90 \%$ of the data generated are in unstructured mode (KUMAR; DABAS, HOODA, 2017), or in more poetic words, "when data manifests it makes

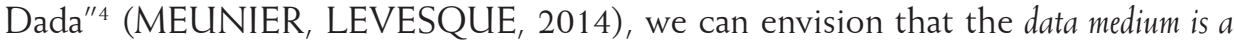
very large, complex and chaotic environment. As Dumbill $(2012$, p. 4) puts it:

As a catch-all term, "big data" can be pretty nebulous [...] web server logs, traffic flow sensors, satellite imagery, broadcast audio streams, banking transactions, MP $3 \mathrm{~s}$ of rock music, the content of web pages, scans of government documents, GPS trails, telemetry from automobiles, financial market data, the list goes on. Are these all really the same thing? To clarify matters, the three $V_{s}$ of volume, velocity and variety are commonly used to characterize different aspects of big data. They're a helpful lens through which to view and understand the nature of the data.

A critic of the Web 2.0 design options, the computer scientist Jaron Lanier (2010) argues that the data accumulation model was an ideological option for the purpose of alienating users, because instead of providing autonomy to the subject, the Web 2.0 made it part of the information system. The author points out that pre-programmable models by users were considered as formats that would bring more freedom and capacity to act, yet companies in the computer segment opted for limited software with profit purposes. According to Lanier (2010), the design options adopted in Web 2.0 express an irony, because the ideology of freedom behind the free flow of data and anonymity brings greater freedom to machines rather than to users. Such design options massively contribute to the structuring of an inhuman and limited artificial intelligence. Acting under an illusion of autonomy, the user of social networks is actually performing moves based on models previously programmed for large-scale data flow, thus becoming the very product to be marketed. The preferences of the users and the behaviour patterns of a social group become commodities for large corporate conglomerates. The ideologies of freedom and high flows of data sharing are a distraction for profit making.

The technological restrictions expressed in computational designs are directly related to the users' ability to express themselves in digital environments. The concept of affordance (GIBSON, 1986) efficiently illustrates the influence on the individual that a given environment design can exercise, it brings us a reflection

4. Excerpt from the artistic manifesto DataDada that makes a comparison between the nature of digital data and the nonsense Dadaist aesthetics. 
on how a physical environment influences forms of interaction. The author exposes the very simple logic that the earth's surface allows us to stand upon it, however, an elevation of that same surface could benefit the action of sitting, therefore "different layouts afford different behaviors" (Gibson, 1986, P. 128).

Gibson (1986) exposes the idea that changes in natural environments have led to corresponding transformations over individuals' relationship with the environment and among themselves. This can lead us to forget or disregard how environments are designed to stimulate different modes of interaction. In the last decades, environmental transformations have also started interfering in the most substantial relations of language. Just like natural landscapes have been replaced by leveling and concrete modifying human behavior, speech, a basic element of human communication, has been replaced in many significant situations by technological devices through which language materializes.

After considering the way that McLuhan approaches media as extensions, Webb Keane and Michael Silverstein (2017) pointed that his view was a deterministic one since it understands the tools of the media as external and immaterial agent. For the authors, the idea of affordance would be a more interesting way of looking at media influences, because it is an ambivalent concept that accepts the objectivity of the material world but does not pose itself as deterministic for human practices, "the point of affordance is that an affordance is only a possibility that may or may not be taken up. It's a real possibility, but whether it's taken up is not itself determined in any useful or meaningful" (KEANE; SILVERSTEIN, 2017, p.34). Taking into account Keane and Silverstein's (2017) point of view, it is important to highlight that, in times of digital mass media, the agent proposing extensions is no longer in a dematerialized or indeterminate locus, but as pointed out by Lanier (2010), computer designs and its consequent tools are options previously chosen and determined by companies in the technology sector.

\section{THE LINGUISTIC ISSUE}

In linguistic studies from the 20th century, "context" has become an essential element for anchoring and understanding meaning (MALINOWSKI, 1923; FREGE, 1980; HALLIDAY, 1999), and consequently for the performative act (AUSTIN, 1963):

To make our utterance performative, and quite unambiguously so, we can make use, in place of the explicit formula, of a whole lot of more primitive devices such as intonation, for instance, 
or gesture; further, and above all, the very context in which the words are uttered can make it entirely certain how they are to be taken. (AUSTIN, 1963/2008, p. 329)

If we consider that linguistic practices are articulated in media contexts (hardware and software), the scales and resources of these media become significant features to comprehend semantic productions and linguistic performances in contemporary times. The artificial medium, produced from computational designs, alters the entire contextual mesh, hence the utterance environment and time, even reconfiguring speaker and audience possibilities. For example, the performative effects of a given statement may undergo scaling modulations if any post on a social network operates from paid tools to boost the visibility of the text. The same is true for the use of bots to boost election campaigns. Taking into consideration the maxim of McLuhan (1964), that the medium is the message and not its linked content, we can assert that in this context of electoral campaigns, the message is a wide performative scope and, therefore, carries in itself political strategies.

Some authors have used the concept of context collapse (MARWICK, BOYD, 2010; VARIS, 2014) to articulate this new media context (especially determined by Web 2.0 design choices). Context collapse refers to media spaces where distinct situations and people overlap, such as in social networks, where co-workers, friends, family, unknown people mix, with online statements directed to a very varied audience. As a consequence of a complex social context, we will have complex semantic productions and performative practices. Writing about the same problem from another perspective, David Porter (1997) indicates that users of the digital environment by the little they choose to disclose become faceless subjects, without bodies, stories, and signatures, in their experimental and anonymous online practices. The words then become "stripped of context, words desperately burdened by the lack of the other familiar markers of identity in this strange, ethereal realm" (PORTER, 1997, p. XII). In this way, anonymity, an outcome from Web 2.0 design, results in the absence of contextual markers, consequently leading to experimental and creative anchors of meaning by the audience. The notions of digital environments presented by these authors indicate a reality of disorderly, highly diverse and insufficiently marked contexts.

In the collapsed context there is a mass of corresponding texts, the hypertext; an endless extension of unstructured multimedia information, generating a big data of complex meaning, a phenomenon distinct from the common significant linearity. If we still consider the Saussurean logic that "the value of just any term is accordingly determined by its environment" (SAUSSURE, 1959, p. 116), in a 
superdiverse environment (that works as an extension of the mind), constantly updated, the meanings (imprecise by nature) acquire an even more complex inaccuracy.

Superdiversity $^{5}$ (BLOMMAERT; BACKUS, 2013) designates the linguistic and socio-cultural heterogeneity resulting from global communication systems such as the internet and migratory processes. For Jan Blommaert (2012) the highly diverse environments of the post-Cold War gave cause to a radical transformation of interaction models based on highly diverse linguistic resources and the consequent complexity of semiotic forms.

Considering the characteristics of the digital medium interactions, such as high scales of velocity, volume and data variation, we can observe that semantic anchors correspond to the unstructured and superdiverse context of linguistic exchanges. This superdiverse context operates with high rates of information and accelerated updating of the textual mesh. The meanings are produced and received from technologically configured indexes, possibly leading the user to unconventional reading processes.

Regarding the interference of big data media for semantic elaboration, another relevant point to take notice is that not only the syntagmatic axis of language changes through hypertexts, but the associative linguistic relations mentioned by Saussure (1959), the mnemonic aspect of language is radically altered by the collapsing superdiverse context. The psychic associations that generate linguistic value now have an extensive, fragmented and unstructured chain of linguistic relationships: a hypertextual chain derived from computational designs previously configured by large and profitable companies.

Knowing that technological mediums are not structures free from ideologies, but projects designed for certain purposes, it is necessary that the linguistic sciences commit to understanding the deepest characteristics of these technological structures. How can we investigate semantic transactions and performative practices in a complex and unstructured environment that is rapidly altered by more diverse forces? How have big tech companies like Google, Facebook and others guided or influenced pragmatic and discursive experiences? In the $21^{\text {st }}$ century, to think of the Austinian maxim "how to do things with words", it is necessary to understand the permissiveness promoted by the media or the ways in which to transgress it.

5. Vertovec (2007) uses "superdiversity" to differentiate the population diversity in Great Britain that have been suffering a considerable impact in the last three decades from immigrants of different origins (social-economically and legally differentiated), unprecedented in its history; therefore, the local diversity is best represented by the prefix "super", indicating greater levels of cultural heterogeneity. 
Lanier (2010) indicates that the designs presented by Web 2.0 were choices among other models proposed, but that nowadays is wrongly believed to be the only possible way for Web 1.0 to evolve.

The design of the web as it appears today was not inevitable. In the early 1990s, there were perhaps dozens of credible efforts to come up with a design for presenting networked digital information in a way that would attract more popular use. Companies like General Magic and Xanadu developed alternative designs with fundamentally different qualities that never got out the door (LANIER, 2010, p. 8)

To Lanier (2010), this impossibility of seeing different feasible patterns of more humanized design is ratified by a type of technological imprisonment, when it seems impossible to implement changes to a format (of software) already determined and applied. Diverse themes are operated at social networks, but regardless of their relevance or emergency, these will be subjected to the same environment of ephemeral updating pattern, which reveals standardized computational designs and their consequent ideologies. The difference between a publication that reports the negligence of authorities with a certain indigenous population and a chocolate cake recipe may not be greater than their similarity, to some extent they carry the same message, the message of the environment of which they are linked to.

What happens when users of a particular social network see their post with important content disappear or get replaced by something else in a few minutes on the timeline? Has the ideology of extensive and free data flow really provided freedom and autonomy for web users or are there other forces that benefit from information networks? What can we note about illocutionary desires and their social effects when an individual intends to report the neglect of public concern for the Amazon rainforest by posting fire and deforestation reports (quickly overlaid by different content on the timeline) and she/he ends up receiving digital advertising from airline companies with promotional tickets for fun tourist trips to Manaus?

As pointed out in McLuhan's allegory (1964) of Allan Poe's tale (1842/1984), in which only after recognizing object patterns within the water vortex may the sailor outline an escape strategy, to understand the radical effects of new media contexts on language is an urgent topic if we are serious about producing an effective analysis of linguistic phenomena in contemporary times.

For the linguist Geoffrey Nunberg (2012) the word "data" metalinguistically reflects the digital context, because it is a mass noun like "dust". A mass structure like clastic stones where unstructured data is accumulated daily. Considering that this massive content is configured in collapsed contexts, linguistic statements can be linked to the most diverse environments previously not controlled by the 
speaker. The incessant updating of digital media drives the utterances to meanings quite different from what was intended by the speaker, because the media produces a diverse and constant updating of contextual markers and consequently the linguistic values of what has been said.

According to Porter (1997), technological media are providing ambiguities and misinterpretations motivated by the lack of contextual markers. Interlocutors do a creative reading because they connect to their own records and life situations to fill the gaps in the environment. The levels of linguistic performativity (locutionary, illocutionary and perlocutionary) are corresponding to the scalar levels of the big data media, to their context of the intensity of velocity, volume and information variation, and consequently to the affordances of computational designs.

Semantic structure processes and linguistic performance are susceptible to the designs of the media because the media have become extensions of the user, and thus "our identities can be shifted by the quirks of gadgets" (LANIER, 2010, p. 6). If the media radically interferes in language processes, we can assume that various cultural indices such as sexuality, ideologies and political strategies, for example, all corroborate to the reverberations of designs and respective computational scales.

Below (Figure 1), a post on Facebook by cartoonist Ivan Cabral exemplifies the point that the digital medium is not only the neutral transmitter, but an environment that stimulates scales in semantic anchoring and linguistic performativity. 


\section{Ivan Cabral}

18 de março de 2016 .

Essa web é mesmo uma terra sem lei. O pessoal acha que pode dizer tudo, fazer tudo, que não dá em nada... Alguém simplesmente pegou uma charge minha e fez as alterações que quis e deixou minha assinatura. Abaixo as charges original e adulterada:

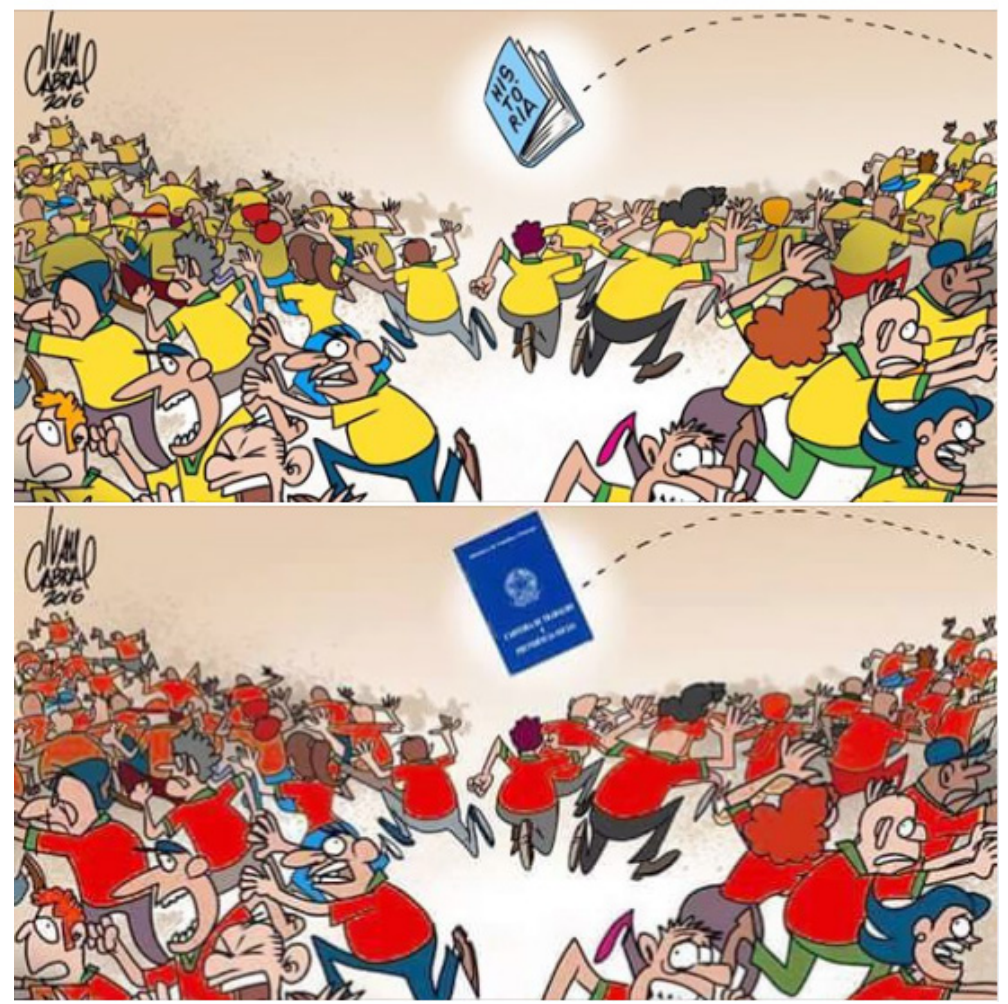

Figure 1. Cartoonist Ivan Cabral's post on Facebook.

Font:https://www.facebook.com/IvanCabral.chargista/posts/10153344329651555? tn $=\mathrm{H}-\mathrm{RH}-\mathrm{R}^{6}$

Post translation: "This web is a no man's land indeed. People think they can say it all, do it all and no repercussions will come from it...Someone simply took a cartoon of mine and altered it as pleased keeping my signature. The original cartoon and the modified one are displayed below:"

6. Accessed in March 2016. 
In the original cartoon, positioned on the top of the image, the characters are dressed up with a yellow T-shirt, in reference to the protests against the Workers' Party and in favor of president Dilma Roussef's impeachment in 2016, when protesters turned the traditional Brazilian jersey into an identity icon of their ideologies. The artist presents a critical cartoon in which these protesters run frightened away from a History book. However, his cartoon was altered and spread online, but this time with the characters wearing red T-shirts (in reference to the Workers' Party and leftwingers). The History book (from the original cartoon) was replaced by a work permit, producing the ironical critic that people bonded by left-wing ideologies and to the Workers' Party do not actually want to work.

Notice how the permissiveness of the medium, through image editing and statement mass dissemination, leads to an ambiguity between the illocutionary desire and the unfolding of perlocutionary effects. The artist says "Someone simply took a cartoon of mine and altered it as pleased keeping my signature". In the next image (Figure 2), we can see the modified cartoon, which was published on the social network page of Rachel Sheherazade, a conservative journalist in Brazil. 


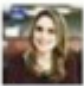

Pessoal acabaram de jogar um artefato que dispersou uma multidão que fazia uma manifestação a favor do Lula e Dilma. Segue foto tirada no momento exato desse ato que ainda não fol apurado o numero de vitimas.
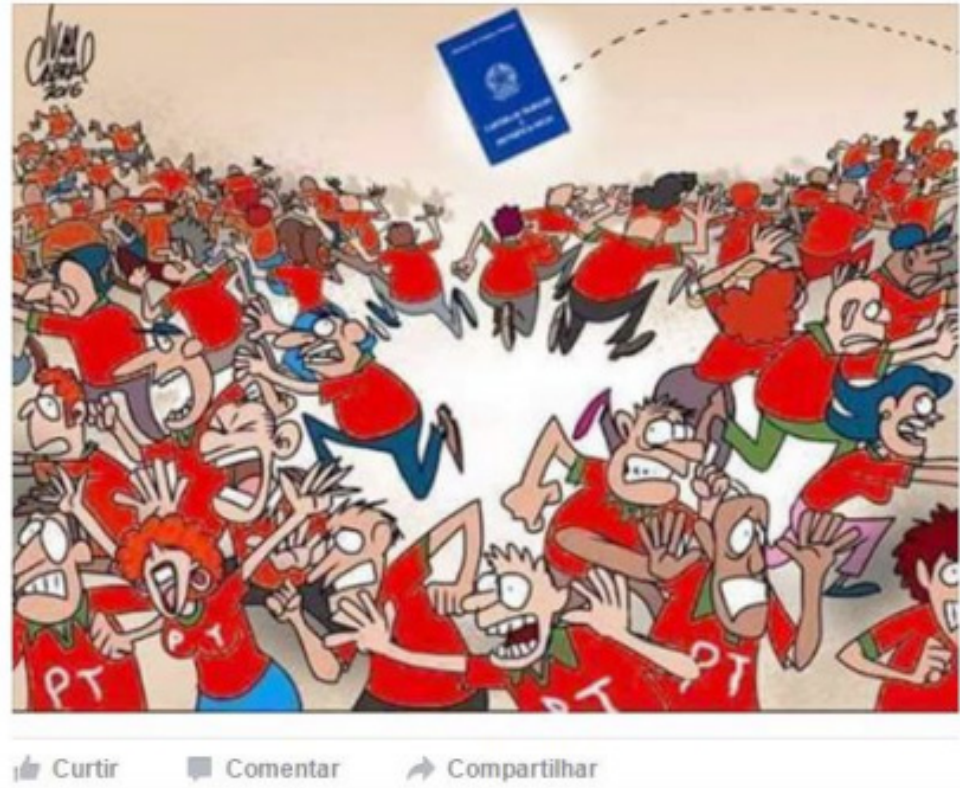

\section{$0 \ddot{0} 91$ mil}

Principais comentários *

79.700 compartilhamentos

3,4 mil comentários

Figure 2. Rachel Sheherazade's post on Facebook.

Font:https://www.facebook.com/RachelSheherazade01/photos/a.404251809679414.1073741 831.304120173025912/829676117136979/?type=3\&pnref=story ${ }^{7}$

Post translation: Guys, they have just thrown an object that dispersed a crowd that was marching in favor of Lula and Dilma. It's a photo taken at the exact moment of this act and the number of victims is unknown.

The modified cartoon, published by the journalist, was reposted by different users almost 80 thousand times. In the same period, the artist's authentic post did not exceed 100 reposts. The social scope of the altered cartoon is considerably

7. Accessed in March 2016. This Facebook account is currently disabled. 
higher and still maintains the author's identity, not only in the signature but also in the personal design feature. Online statements are stimulated by digital media scales, and, in this case, for all intent and purposes, the cartoonist said what he did not actually said, in other words, the perlocutionary effects were opposed to bis original intention, bis locutionary desire.

Austin's premise of action through words needs to be extended to the new context of media societies. This is important because the scalar levels of environment and social range have expanded radically. Hackers are a paradigmatic example of how media permissiveness applies limits or can be transgressed through an autonomy not allowed by computer design. Hackers are individuals who, by mastering certain media resources, become able of non-prescribed levels of illocution. They are the updated version of Allan Poe's sailor's McLuhian allegory.

\section{CONCLUSION}

If, on one hand, computational designs of the Web 2.0 environment as affordances (Gibson, 1986) have the power to stimulate or limit linguistic practices, on a broader level they allow powerful political actions and strategies to be done. The use of big data personal information for election campaign purposes, such as the data analysis that the company Cambridge Analytica has done, is an example for this. Alexander Nix, CEO of that company, pointed out that thousands of data were collected from individuals, ranging from ice cream preferences to newspapers, football teams and affiliation to political parties, creating distinct categories of profiles for configuring political strategies; meanwhile the former director of research at Cambridge Analytica, Christopher Wylie, stated that technology companies are colonizing us (LOPES, 2019).

Disinformation processes like fake news and massive spreading of social bots, tools for successful campaigns like Brexit, Trump and Bolsonaro (LOPES, 2019), are only possible due to the design choices made by the same companies that commercially transfer data for mining and analysis. Such political strategies developed from changing contextual scales such as velocity and volume of information and anonymity. Anonymity is an important and helpful element for freedom in digital environment, especially when there are reprisals or imminent danger to the user. The Arab Spring is a great example of that, when anonymity and the use of deep web allowed the forbidden information flow (ABREU; NICOLAU, 2014). The downside is the use of anonymity for massive spreading of fake news and verbal racist insults, for example. According to Lanier (2010), for other than 
the benefits, there is an ideological incentive for anonymity in Web 2.0, because it collaborates with a common and faceless artificial intelligence, although very profitable among the hegemonic data trading.

Lanier (2010) makes one of the most important scores of his work when he says that the technological imprisonment of software design is so powerful that it makes us forget that things could be different, or that other computational design patterns could be used. In his words:

The corresponding philosophies of how humans can express meaning have been so ingrained into the interlocked software designs of the internet that we might never be able to fully get rid of them, or even remember that things could have been different (LANIER, 2010, p.12)

It seems reasonable to assert that the logic presented by Lanier (2010) is in accordance with the Gramscian question of hegemony, the idea that established social standards are socially produced and not natural life facts. Blommaert (2019) associates Gramsci's thinking with the current model of Web 2.0, when he points to the fact that the internet is a Gramscian system in the sense that it incorporates ideologies. The dominant ideology that intercepts daily communication comes from large groups of computational capital, and has been increasingly limiting an individual's ability of autonomy and action. The option of keeping people bounded to common and limited gadgets (through which large and tradable amounts of data can be collected) seemed more attractive than options focused on the individual's emancipation in media relations.

The investigate of semantic transactions and performative practices in digital environments must consider the design of the software through which messages are propagated. Understanding media permissiveness and limitations is fundamental to comprehending linguistic practices of social agents. As the cartoon was modified and replicated at considerably larger scales than the original, it is not possible to carry out an analysis of the object without criticizing how it was stimulated by the media resources. To understand how this new scenario affects political and linguistic occurrences, semantic anchoring, performative practices and the configuration of social hegemonic discourses is an inescapable task for linguistic studies in the beginning of this century.

Big tech companies like Google and Facebook guided and stimulated pragmatic and discursive experiences through their software designs provided to users. Sociolinguistic researchers are in an important position to contribute to the challenge of how computational designs can be projects for more democratic purposes, such as encouraging users' autonomy and the restriction of fake news. Lanier (2010) clarifies that small changes in the details of a digital design can have 
profound effects on the behaviors and experiences of the users. The technological prison, the incentive for undue anonymity, and the idea that software is a rigid structure, must all be criticized for healthier digital affordances to be possible.

\section{REFERENCES}

ABREU, G.; NICOLAU, M. (2014). A estética do anonimato na Deep Web: a metáfora das máscaras e do homem invisível aplicada ao "submundo" da internet. Culturas Midiáticas, v. 7, $\mathrm{n}^{\circ}$ 1, (pp. 119-134).

AUSTIN J. (1963). Speech Acts and Convention "Performative-Constative". In: NUCCETELLI, S. \& SEAY, G. (eds.), Philosophy of language: The central topics (2008). New York: Rowman and Littlefield.

BLOMMAERT, J. (2012). Ethnography, superdiversity and linguistic landscapes: chronicles of complexity. Bristol: Multilingual Matters.

BLOMMAERT, J.; BACKUS, A. (2013). Superdiverse Repertoires and the Individual. In SAINT-GEORGES I; WEBER J. (eds.), Multilingualism and Multimodality: Current Challenges for Educational Studies. Rotterdam: Sense Publishers, (pp. 11-32).

BLOMMAERT, J. (2019). Professor Jan Blommaert on Gramsci and the internet. Retrieved from <https://www.youtube.com/watch?v $=$ mwHPW8KxVHI\&t $=321 \mathrm{~s}>$. Last accessed: 05 Jan. 2020.

CRYSTAL, D. (2001) Language and the Internet. Cambridge: Cambridge University Press.

DUMBILL, E. (2012). What Is Big Data?. In: DUMBILL E. (ed.), Planning for Big Data. Sebastopol: O'Reilly Radar Team.

FREGE, G. (1980). The Foundations of Arithmetic. Trans. J. L. Austin. Oxford: Basil Blackwell.

GIBSON, J. (1986). The ecological approach to visual perception. New Jersey: Lawrence Erlbaum.

HALLIDAY, M. A. K. (1999). The notion of "context" in language education. In GHADESSY, M. (ed.) Text and context in functional linguistics. Amsterdam: John Benjamins Publishing Company, (pp.1-24). 
JAKOBSON, R. (1960). Closing statement: Linguistics and poetics. In: SEBEOK, T. A. (ed.). Style in Language. Cambridge: MIT Press, (pp. 350-377).

KEANE, W.; SILVERSTEIN, M. (2017). Curated Conversation: "Materiality: It's the Stuff!". In: CAVANAUGH, J; SHANKAR, S (eds.), Language and Materiality: Ethnographic and Theoretical Explorations. Cambridge: Cambridge University Press.

KUMAR, A.; DABAS, V.; HOODA, P. (2017). Text classification algorithms for mining unstructured data: A SWOT analysis. In: HODA, M. N. International Journal of Information Technology. Delhi: Springer, (pp. 1-11).

LANIER, J. (2010). You Are Not a Gadget: A Manifesto. New York: Alfred A. Knopf.

LOPES, P. (2019). Mentiras, pegadas e algoritmos: da necessidade de uma educação para os media. In: LOPES, P. \& REIS, B. (eds.), Comunicação Digital: media, práticas e consumos. Lisbon: NIP-C@M \& UAL, (pp. 137-156).

MALINOWSKI, B. (1923). The problem of meaning in primitive language. In: OGDEN, C. K. and RICHARDS I. A. (eds.), The meaning of meaning. London: Routledge \& Kegan Paul, (pp. 296-336).

MARWICK, A.; BOYD, D. (2010). I tweet honestly, I tweet passionately: Twitter users, context collapse, and the imagined audience. New Media \& Society, v. $13, \mathrm{n}^{\circ} 1$, (pp. 114-133).

MCLUHAN, M. (1964). Understanding Media: The Extensions of Man. New York: McGraw-Hill.

MEUNIER, A.; LEVESQUE, J. (2014). Manifesto datadada. Retrieved from: < https:// data-dada.net/en/>. Last accessed: 19 Dec. 2019.

NUNBERG, G. (2012). Forget YOLO: Why 'Big Data' Should Be The Word Of The Year. Retrieved from: <https://www.npr.org/2012/12/20/167702665/geoff-nunbergsword-of-the-year-big-data >. Last accessed: 20 Dec. 2019.

POE, E. A. (1984). A descent into the maelström. In: Poetry and tales. New York: The Library of America, (pp. 432-48).

PORTER, D. (1997). Introduction. In: PORTER D. (ed.), Internet culture. London: Routledge, (pp. xi-xviii). 
RAJAGOPALAN, K. (2013). Como o internetês desafia a linguística. In: SALIÉS, T. G.; SHEPHERD, T. G. Linguística da Internet. São Paulo: Contexto, (pp. 37-53).

SAUSSURE, F. (1959). Course in General Linguistics. Trans. Wade Baskin. New York: Philosophical Library.

SOUSA, J.; CURVELLO, J.; RUSSI, P. (2012). 100 anos de McLuhan. Brasilia: Casa das Musas.

VARIS, P. (2014). Digital Ethnography. In: Georgakopoulou A.; Spilioti T. The Routledge Handbook of Language and Digital Communication. London: Routledge, (pp. 55-68).

VERTOVEC, S. (2007). Super-diversity and its implications. Ethnic and Racial Studies, v.30, n. 6, (pp. 1024-1054).

ZIKOPOULOS, P. (2012). Understanding Big Data: Analytics for Enterprise Class Hadoop and Streaming Data. Aspen: McGraw-Hill.

Recebido: 20/02/2020

Aceito: 13/04/2020

Publicado: 15/04/2020 